\title{
DIAKRONIKA
}

Vol. 19 No. 1 Th. 2019 p: 26-40

ISSN: 1411-1764 (Print) | 2620-9446 (Online)

http://diakronika.ppj.unp.ac.id

\section{Sejarah Lokal Riau untuk Pengembangan Materi Ajar Sejarah Indonesia Kelas XI SMA}

\author{
Asyrul Fikri \\ asyrul.fikri@lecturer.unri.ac.id \\ Universitas Riau
}

\begin{abstract}
Results of the study aims to integrate local history that is in the Riau into festive the history of Indonesia material of class XI. The method used is the analysis of documents, namely documents the history of Indonesia syllabus of class XI. Historical events that happened in Riau are integrated and analyzed to each basic competence in accordance with the learning material. Results of the study are, among others, the local people's struggle history of Riau do resistance to colonization a foreign nation such as the people's resistance war Guntung, war Reteh, war Mondang Kumango, resistance Tuanku Tambusai, resistance Datuk Tabano, Resistance Raja Haji, Sultan Zainal Abidin, War and resistance Manggris and Pirates in waters of Riau can be integrated into the basic competence to analyze the process of entry and the development of European colonization (Portugal, Spain, Netherlands, United Kingdom) to Indonesia with the material of Learning Strategies of resistance against Indonesia nation of European colonialism until the beginning of the 20th century. Integration of the study of local history in the process of learning history in class is expected to improve the understanding and awareness of the students against the local local history and its relationship with national history.
\end{abstract}

Keywords:Local History, Material, The History Of Indonesia

\begin{abstract}
Abstrak
Hasil kajian bertujuan untuk mengintegrasikan sejarah lokal yang ada di Riau ke dalam materi ajar Sejarah Indonesia kelas XI. Metode yang digunakan adalah analisis dokumen yaitu dokumen silabus Sejarah Indonesia kelas XI. Peristiwa-peristiwa sejarah yang terjadi di Riau diintegrasikan dan dianalisis ke setiap masing-masing kompetensi dasar sesuai dengan materi pembelajaran. Hasil kajian antara lain, sejarah lokal perjuangan rakyat Riau melakukan perlawanan terhadap penjajahan bangsa asing seperti Perang Guntung, Perlawanan Rakyat Reteh, Perang Mondang Kumango, Perang Tuanku Tambusai, Perang Datuk Tabano, Perlawanan Raja Haji, Perlawanan Sultan Zainal Abidin, Perang Manggris dan Perlawanan Lanun di Perairan Riau dapat diintegrasikan ke dalam kompetensi dasar menganalisis proses masuk dan perkembangan penjajahan bangsa Eropa (Portugis, Spanyol, Belanda, Inggris) ke Indonesia dengan materi pembelajaran Strategi perlawanan bangsa Indonesia terhadap penjajahan bangsa Eropa sampai awal abad ke-20. Integrasi kajian sejarah lokal dalam proses pembelajaran sejarah di kelas diharapkan dapat
\end{abstract}


meningkatkan pemahaman dan kepedulian peserta didik terhadap sejarah lokal setempat dan hubungannya dengan sejarah nasional.

Kata Kunci:Sejarah Lokal, Pengembangan Materi,Sejarah Indonesia

(c) (D) (?) This work is licensed under the Creative Commons Attribution-ShareAlike 4.0 International License.

\section{Pendahuluan}

Pembelajaran sejarah menekankan pada usaha memproyeksikan masa lampau itu ke masa kini, sebab dalam masa sekarang, masa lampau tersebut menjadi masa lampau yang bermakna. Menurut Carr (2014), sejarah sebagai dialog berkesinambungan antara masa sekarang dan masa lampau. Oleh karena itu, guru sejarah dituntut untuk mengembangkan metode pengajaran yang dapat membantu peserta didik untuk menangkap dan memahami peristiwa sejarah secara lebih bermakna. Sejarah dalam konteks pendidikan adalah untuk mengabadikan pengalaman masyarakat di waktu lampau sebagai bahan pertimbangan untuk memecahkan masalah-masalah yang dihadapinya. Melalui sejarah, nilai-nilai masa lampau dapat dipetik dan dimanfaatkan untuk menghadapi masa kini. Seperti yang diungkapkan oleh Renier dalam Widja (1989), tanpa masa lampau orang tidak akan mampu membangun ide-ide tentang konsekuensi dari apa yang dia lakukan.

Pembelajaran sejarah hendaknya benar-benar disadari dan ditekankan suatu usaha untuk menghayati atau menghargai nilai-nilai masa lampau yang berorientasi untuk kepentingan masa yang akan datang. Prinsipnya yaitu, bahwa apa yang kita perbuat sekarang adalah demi hasil yang akan dimanfaatkan diwaktu yang akan datang. Pembelajaran sejarah perlu diluruskan hanya sekedar penguasaan fakta-fakta sejarah dan hanya fokus pada masa lampau saja. Pembelajaran sejarah perlu diusahakan oleh guru sejarah yaitu agar peserta didik secara dinamis mengamati pengalaman masa lampau dari generasi terdahulu, menemukan konsep-konsep atau ide-ide dasar dalam peristiwa masa lampau yang nantinya diharapkan dapat membekali dirinya dalam menilai perkembangan masa kini dan di masa yang akan datang. Artinya masa lampau itu semestinya diharapkan akan memberikan nilai-nilai yang berupa semangat sebagai cerminan dinamika masyarakat pada masa itu dalam menghadapi tantangan atau permasalahannya pada zamannya.

Misalnya dari peristiwa perjuangan dan perlawanan terhadap penjajahan Belanda di Indonesia. Dari peristiwa tersebut dapat direalisasikan dalam berbagai bentuk perlawanan, sesuai dengan situasi serta tantangan 
pada zaman tersebut. Jika dikaitkan dengan keadaan pada masa kini, tentu saja situasi serta tantangan zaman yang berbeda dan telah berubah yaitu lebih menekankan pada pembangunan di segala bidang. Maka nilai-nilai yang dapat diambil dari peristiwa masa lampau tersebut adalah semangat berjuangnya yang dalam merealisasikannya disesuaikan dengan situasi dan tantangan zaman sekarang bahkan dimungkinkan untuk proyeksi pada masa yang akan datang. Untuk itu guru sejarah perlu menggunakan strategi untuk mencapai pembelajaran sejarah yang lebih bermakna tersebut. Salah satunya adalah dalam pengembangan materi ajar sejarah yang dekat yang dapat dikaitkan dengan sejarah lokal.

Seperti yang diungkapkan oleh (Wasino \& Cina, 2007) bahwa Pembelajaran sejarah hendaknya dimulai dari fakta-fakta sejarah yang dekat dengan lingkungan tempat tinggal anak, baru kemudian pada fakta-fakta yang jauh dari tempat tinggal anak. Materi ajar sejarah yang ada di buku-buku teks pelajaran berorientasi pada ruang lingkup Sejarah Nasional. Bahkan beberapa peserta didik tidak tahu nama tokoh pahlawan yang ada di daerahnya sendiri. Hal ini menjadi tugas bersama khususnya guru sejarah untuk mendekatkan peserta didik pada sejarah yang ada di lingkungan sekitarnya. Mengutip penggalan puisi karya WS Rendra yang berjudul Sajak Seonggok Jagung, “ ......Pendidikan telah memisahkannya dari kehidupannya. Aku bertanya: Apakah gunanya pendidikan?. Bila hanya akan membuat seseorang menjadi asing di tengah kenyataan persoalannya?.....".

Belajar sejarah dimaksudkan agar seseorang mengetahui, memahami dan mampu mengambil makna atau hikmah dari peristiwa-peristiwa masa lampau. Belajar sejarah daerah-daerah lain, sejarah negara-negara atau bangsa-bangsa lain namun lebih utama dari itu adalah belajar sejarahnya sendiri atau sejarah daerahnya sendiri. Sebagai suatu perumpamaan dan refleksi adalah manakah lebih bermakna pembelajaran sejarah jika peserta didik dari daerah Riau lebih mengetahui Perjuangan Pangeran Antasari dari Banjarmasin dan tidak mengetahui Perjuangan Panglima Tengku Sulung dari Riau. Untuk itu kajian ini bertujuan untuk menintegrasikan dan mengaitkan materi pelajaran Sejarah Indonesia kelas XI (sebelas) SMA dengan peristiwa sejarah lokal yang ada di Riau berdasarkan analisis kompetensi dasar yang ada pada dokumen silabus mata pelajaran Sejarah Indonesia kelas XI (sebelas) SMA.

Sejarah lokal merupakan pendukung dari perkembangan Historiografi Indonesia. Bahkan menjadi kerangka dalam penyusunan Sejarah Nasional Indonesia yang menurut Lapian (2008) memperluas pandangan tentang dunia Indonesia. Sejarah lokal dapat diartikan sejarah dengan ruang lingkup Spasial (wilayah) di bawah sejarah nasional. Sejarah lokal adalah suatu bentuk 
penulisan sejarah dalam lingkup yang terbatas yang meliputi suatu lokalitas tertentu (Widja, 1989). Sejarah lokal menurut Abdullah (2010) barulah ada setelah munculnya kesadaran sejarah nasional. Sejarah lokal diartikan sebagai studi tentang kehidupan masyarakat atau khususnya komunitas dari suatu lingkungan sekitar (neighborhood) tertentu dalam dinamika perkembangannya dalam berbagai aspek kehidupan manusia (Widja, 1989). Sejarah lokal dalam konteks proses pembelajaran sejarah sangat diperlukan untuk membangkitkan kesadaran sejarah nasional serta mendidik peserta didik untuk peduli dan memahami nilai-nilai peristiwa sejarah yang ada di lingkungan sekitarnya.

Namun mata pelajaran sejarah sendiri sering dianggap sebuah mata pelajaran yang kurang disukai oleh peserta didik. Alasan yang diberikan bermacam-macam. Umumnya dikarenakan pada materi ajar sejarah yang terkait dengan banyaknya hafalan angka-angka tanggal, tahun, nama peristiwa, nama tempat, dan tokoh yang bagi peserta didik sangat tidak menarik dan menjemukan. Selain itu belajar sejarah membosankan dikaitkan dengan figur guru sejarah yang kurang profesional dalam mengajar sejarah. Banyak guru menyampaikan materi secara texbook, tanpa variasi, monoton, kurang humor, dan tetap menggunakan metode ceramah yang membosankan. Pembelajaran sejarah pun menjadi kaku dan tidak bermakna. Hal ini bisa jadi disebabkan oleh tidak maksimalnya pemanfaatan media belajar seperti mempergunakan peta, foto, replika candi, dan lain-lain. Di tambah lagi, guru sejarah memberikan soal dan pertanyaan yang sulit-sulit.

Di sisi lain ada kemungkinan ketidaktertarikan peserta didik pada mata pelajaran sejarah lebih pada ruang lingkup materi ajar sejarah yang kurang menyentuh rasa kedaerahan mereka, sehingga rasa keterlibatan dan emosionalnya tidak terbentuk secara alamiah. Oleh karena itu, salah satu upaya untuk mengembalikan minat belajar peserta didik terhadap pelajaran sejarah adalah dengan menggunkan pendekatan pembelajaran sejarah yang terkait dengan situasi lingkungan sekitarnya. Kegiatan pembelajaran sejarah lokal perlu dijadikan medium untuk mengembangkan rasa kepedulian dan ketertarikan akan ranah kedaerahan mereka, untuk selanjutnya menggali lebih mendalam lagi tentang apa yang pernah ada dalam lintasan masa lalu di daerahnya. Proses aktualisasi nilai-nilai sejarah dalam kehidupan yang nyata dalam konteks pembelajaran sejarah lokal menghasilkan suatu kesadaran sejarah yang dapat dikatakan sebagai kondisi kejiwaan yang menunjukkan tingkat penghayatan pada makna dan hakekat sejarah yang ada dilingkungan sekitar peserta didik.

Belajar sejarah pada dasanya merupakan belajar tentang kehidupan masyarakat. Berbagai aspek kehidupan dapat dipelajari dalam sejarah atau 
kehidupan masyarakat masa lampau tersebut. Oleh karena itu, sudah semestinya pembelajaran sejarah di sekolah mudah dipahami peserta didik. Dalam pembelajaran sejarah hendaknya peserta didik dapat melihat langsung kehidupan yang nyata. Oleh karena itu sejarah lokal dalam konteks pembelajaran di sekolah tidak dibatasi oleh ruang lingkup yang bersifat administratif seperti sejarah provinsi, sejarah kabupaten, sejarah kecamatan, dan sejarah desa. Berdasarkan sejarah lokal tersebut, peserta didik dapat menyadari dan lebih mengembangkan tema-tema kehidupan yang terjadi dalam lingkungan masyarakat sekitarnya, sehingga peserta didik dapat lebih memahami dan memaknai peristiwa sejarah. Berbagai Pendekatan atau metode pengajaran dapat digunakan guru sejarah dalam pembelajaran sejarah. Namun masing-masing tentu memiliki kelebihan dan kekurangan.

Oleh karena itu, pemilihan suatu pendekatan pengajaran akan sangat tergantung pada tujuan atau sasaran yang hendak dicapai yang biasanya sudah ditentukan dalam kurikulum dan pertimbangan lainnya. Hal ini juga berlaku pembelajaran sejarah dengan pendekatan pada sejarah lokal. Menurut Widja (1989), pembelajaran sejarah dengan pendekatan sejarah lokal memiliki beberapa kelebihan dan kekurangan. Kelebihannya yaitu dapat membawa peserta didik pada situasi riil di lingkungannya bahkan seakan-akan mampu mendobrak batas antara dunia sekolah dan dunia nyata di sekitar sekolah. Secara sosiologis-psikologis dapat dikatakan membawa peserta didik secara langsung mengenal serta menghayati lingkungan masyarakatnya. Peserta didik lebih muda dibawa pada pengalaman belajar untuk memproyeksikan pengalaman masa lampau masyarakatnya dengan situasi masa kini dan juga masa yang akan datang.

Selain itu, peserta didik akan mendapatkan banyak contoh-contoh dan pengalaman-pengalaman dari berbagai tingkat perkembangan lingkungan masyarakatnya. Dengan kata lain, mereka akan lebih mudah memahami konsep waktu atau perkembangan atau perubahan yang menjadi kunci keterkaitan antara masa lampau, masa kini dan masa yang akan datang. Pembelajaran sejarah di kelas dengan pendekatan sejarah lokal akan sangat mendukung prinsip pengembangan kemampuan murid untuk berpikir aktif kreatif serta struktural konseptual. Peserta didik akan terdorong untuk mengembangkan keterampilan-keterampilan khusus seperti mengobservasi, teknik bertanya atau melakukan wawancara, mengumpulkan serta menyeleksi sumber, mengadakan klasifikasi serta mengidentifikasi konsep, bahkan juga membuat generalisasi sehingga tercapainya proses belajar yang bersifat discovery/ inquiry. Hal ini sesuai dengan tujuan NCHS (Hasan, 2007), yaitu tujuan pendidikan sejarah adalah historical thinking, historical analysis and interpretation, dan historical research capabilities. 
Namun ada beberapa hal yang menjadi kendala-kendala dalam pembelajaran sejarah lokal seperti terbatasnya sumber-sumber sejarah lokal, karena guru maupun peserta didik dihadapkan pada sumber-sumber sejarah baik yang tertulis maupun lisan. Jadi seorang guru dituntut untuk memahami dan harus mampu menguasai metodelogi dalam sejarah. Kesulitan lain adalah memadukan tuntutan pembelajaran sejarah lokal dengan tuntutan penyelesaian target materi yang ada dalam silabus. Ini biasanya terkait dengan tuntutan peserta didik yang akan menempuh tes baik di lingkungan sekolah maupun di luar sekolah. Hal ini dikarenakan materi sejarah lokal yang sulit dikaitkan dengan persiapan peserta didik menghadapi tes-tes yang bersifat nasional.Banyak sekali keunggulan dan kelebihan yang dapat diperoleh dari model kegiatan pembelajaran sejarah lokal. Keberhasilan pembelajaran sejarah lokal dapat didasarkan pada pilihan dari model pembelajaran sejarah lokal itu sendiri yang cukup beragam.

Pembelajaran sejarah lokal membutuhkan kesiapan pengorganisasian yang cukup matang dari pengajar sehingga program yang bertujuan dan berdaya guna baik itu tidak sia-sia saja. Terdapat beberapa alternatif model pembelajaran bagi guru sejarah untuk lebih mengeskplorasi materi sejarah lokal. Pertama, tipe penyajian informasi sejarah lokal dari pengajar kepada peserta didik tanpa mengharuskan peserta didik berada di lapangan. Model dan tipe ini masih konvensional seperti metode pembelajaran sejarah lainnya yang mungkin membuat peserta didik tetap merasa jenuh dan bosan.Kedua, pengajar dapat membuat model penjelajahan lingkungan sekitar. Tipe ini dapat diterapkan pada peserta didik baik yang masih di sekolah dasar maupun sekolah menengah atas, walau dengan intensitas kedalaman materi dan riset yang berbeda.

Ketiga, pengajar dapat menerapkan model lawatan sejarah sebagai upaya mengeksplorasi kekayaan sejarah lokal dan budaya yang dimilikinya. Menurut Zuhdi (2007) lawatan sejarah adalah suatu program penjelajahan masa lalu melalui kunjungan ke tempat-tempat bersejarah. Tempat bersejarah tersebut dapat berupa makam tokoh, tempat pengasingan, komunitas masyarakat, dan juga pusat-pusat kegiatan ekonomi (Lestariningsih, 2007). Selain itu, pengajar dapat memanfaatkan museum daerah terdekat sebagai sasaran lawatan sejarah. Di dalam museum jelas sekali terdapat berbagai artefak peninggalan masa Hindu-Buddha dan beberapa diorama penyajian peristiwa bersejarah masa prasejarah maupun Indonesia modern (Hartatik, 2007).

Keempat, pengajar dapat memilih model wisata sejarah sebagai sarana mengunjungi situs bersejarah. Model ini mirip sekali dengan lawatan sejarah. Pada model wisata sejarah, peserta didik menikmati obyek sejarah layaknya 
mereka sebagai turis dan berkesan rekreatif. Nuansa penikmatan terhadap panorama keindahan alam lebih ditonjolkan daripada unsur studinya (Nurjanto, 2007). Kelima, pengajar dapat memilih model studi sejarah murni. Artinya, seorang pengajar memberi beban penugasan penelitian sejarah murni kepada peserta didik dengan pembatasan-pembatasan yang sudah diprogramkan sebaik-baiknya. Namun sebelumnya agar tidak terjadi kebingungan peserta didik dan pemborosan waktu, sebaiknya pengajar memberikan dahulu tentang materi riset dan dasar-dasar penelitian sejarah (Widodo, 2009).

Keenam, pengajar memilih model kemah budaya untuk mengeksplorasi tema-tema sejarah lokal. Kemah budaya adalah sebuah kegiatan bersama-sama yang dilaksanakan di sebuah tempat bersejarah dengan cara peserta didik diajak untuk hidup dan tinggal bersama masyarakat setempat (Muslichin, 2011). Model kemah budaya ini menjawab paradigma bahwa sejarah tidak hanya berkaitan dengan masa lalu saja. Kemah budaya justru mampu mengingatkan apa yang dapat kita hindarkan dan mana yang dapat kita pupuk terus sebagai sumber motivasi membangun kebersamaan. Dalam konteks sejarah, kebersamaan justru prioritas dibangun melalui komitmen dan tindakan nyata, seperti halnya dahulu ketika bangsa kita mengusir penjajah (Lestariningsih, 2007; Nurjanto, 2007).Kemah budaya merupakan alternatif pembelajaran yang menarik dan tidak membosankan. Kemah budaya adalah upaya menjadikan sejarah sebagai kata kerja. Sejarah sebagai praktik tentu akan lebih menyenangkan bagi mahasiswa untuk belajar apalagi diimbangi dengan berwisata. Guru dapat mengajak anak didik mengunjungi situs dan monumen sejarah (Zuhdi, 2007).

Pembelajaran sejarah memiliki beberapa manfaat yang sangat berperan dalam proses transformasi pengetahuan kemasyarakatan yang pernah ada di masa lampau yang memiliki keterkaitan dengan peristiwa masa kekinian. Pembelajaran sejarah memberikan muatan-muatan pendidikan karakter, menumbuhkan semangat patriotisme dan nasionalisme, dan memberikan kesadaran reflektif bagi anak bangsa akan masa lalunya. Pembelajaran sejarah lokal memberikan kesadaran pada peserta didik bahwa mereka mempunyai masa lalu sendiri. Mereka memiliki suatu kebanggaan bahwa jauh sebelum mereka dilahirkan ada beberapa tokoh yang berperan dalam membentuk keadaan yang terkait dengan masa sekarang. Kesadaran kontinuitas dan lokalitas ini dapat menjadi bekal pada peserta didik untuk menunjukkan identitas historis, sosial, dan budayanya. Ada ikatan emosional yang tinggi antara peserta didik dengan peristiwa lampau yang terjadi di dalam kelompok masyarakatnya. 
Semakin jauh peserta didik terlibat dalam eksplorasi sejarah lokal berarti semakin tinggi pula jati diri dan kebanggan akan masa lalu kelompok, daerah, dan kebudayaannya. Kesadaran terhadap masa lalu daerahnya ini jangan sampai melahirkan sikap kebanggan kedaerahan (primordialisme) yang berlebihan ke arah yang bersifat negatif. Hal ini justru akan mengurangi semangat persatuan dan kebersamaan antar bangsa yang saat ini sudah tercapai dengan baik. Tujuan peserta didik mempelajari sejarah lokal seperti tokoh perjuangan yang ada di daerahnya adalah untuk memahami bagaimana sikap dan tindakan dari tokoh tersebut mempertahankan wilayah atau negerinya melawan unsur-unsur kebudayaan dan pemerintahan asing yang menindas. Dengan sejarah lokal yang diajarkan dalam kelas maupun luar kelas, berarti peserta didik mengenal secara langsung bagaimana pribadi dan biografi hidup sang pelaku sejarah.

Pembelajaran sejarah lokal memberikan peluang lebih aktif bagi peserta didik untuk menggali informasi secara mandiri terhadap sasaran yang sudah direncanakan. Melalui informasi juru kunci, pamong budaya, dan petugas kebudayaan peserta didik menjadi lebih mengenali karakter sosial dari pelaku sejarah. Bagaimana pelaku sejarah memperjuangkan nilai-nilai ideologi yang mulia dan sesuai dengan konteks kebersamaan dalam hidup masa itu akan memberi inspirasi bagi peserta didik untuk mengamalkan hal yang sama pada kehidupan masa sekarang. Pembelajaran sejarah lokal juga memberikan banyak informasi tentang kebudayaan apa yang berkembang di wilayahnya pada masa lalu. Melalui peninggalan-peninggalan sejarah yang tersisa peserta didik dapat melihat bagaimana posisi geografis dan peran sosial ekonomi-politik daerahnya pada waktu itu. Apakah wilayahnya mempunyai peran sosial yang cukup penting ataukah daerahnya menjadi kawasan peripherial saja misalnya dalam hal proses masuk dan berkembangnya agama Islam di daerah tersebut.

Kesadaran historis ini dapat menghasilkan semangat untuk melakukan perubahan dalam perspektif yang positif pada masa sekarang. Peserta didik menjadi percaya diri untuk mereflesikan diri dari apa yang terdapat pada kekayaan historisnya. Dengan pembelajaran sejarah lokal berarti peserta didik dapat mengambil hikmah dan menerapkannya dalam kehidupan sehari hari seperti gaya kepemimpinan pelaku sejarah yang dapat diterapkan oleh peserta didik pada saat mereka menempati posisi dan profesi pekerjaan masing-masing. Semangat pelaku sejarah yang mengutamakan musyawarah mufakat dalam memutuskan sesuatu hal memberikan dorongan bagi peserta didik dalam memutuskan suatu kebijakan kelak ketika mereka sudah bekerja. Semangat gotong royong memberikan inspirasi nyata bagi peserta didik untuk mendorong etos kerja dan produktivitas kerja ketika peserta didik sudah 
menempati posisi dalam pekerjaan dan perusahaan. Semangat rela berkorban dan mengutamakan kepentingan bersama jelas dapat diterapkan pada iklim dunia kerja tanpa membeda-bedakan latar sosial dan budaya agar perusahaan dapat mencapai prestasi kerja yang tinggi. Peserta didik akan memposisikan dirinya secara nasional bahkan global dengan melihat identitas diri etnik/lokalnya.

\section{Pembahasan}

Permasalahan dalam pengembangan materi pembelajaran sejarah adalah terkait dengan ruang lingkup materi dan isi materi. Pertentangan maupun perdebatan muncul dikalangan para sejarawan dan pemangku kebijakan. Bahkan hal tersebut menjadi melebar kepada hubungan antar negara takkala mengkaji sejarah yang berkaitan dengan negara lainnya. Pada dasarnya permasalahan dalam ruang lingkup materi sejarah berkaitan dengan topik sejarah yang diajarkan di sekolah. Secara garis besar, materi pendidikan sejarah yang diajarkan di sekolah adalah materi sejarah politik seperti tentang perebutan kekuasaan, muncul dan jatuhnya kekuasaan, dan peperangan antara dua kekuasaan dalam memperebutkan hegemoni terhadap suatu wilayah tertentu.

Kurikulum pendidikan sejarah di Indonesia sangat jelas menggambarkan arah tujuan materi ajar sejarah tersebut. Pokok-pokok bahasan yang ada dalam kurikulum sejarah adalah tentang perang, perebutan kekuasaan dan konflik politik. Pokok-pokok bahasan yang berkaitan dengan zaman Hindu-Budha, zaman Islam, zaman penjajahan Belanda, zaman penjajahan Inggeris, masa pendudukan Jepang bahkan ketika Indonesia sudah merdeka maka konflik-konflik politik antar pemerintah pusat dengan daerah, pertentangan antara satu golongan politik dengan golongan politik lainnya. Seiring dengan majunya perkembangan teknologi dan kebebasan berpendapat, kajian-kajian tentang sejarah mudah dicari dan didapatkan. Bahkan kajian mengenai sejarah kontoversi menjadi perbincangan bagi masyarakat umum. Hal ini mempermudah bagi guru sejarah untuk memperkaya dan mengembangan materi ajar.

Pada masa belakangan ini perluasan ruang lingkup materi sudah mulai tampak. Pokok-pokok bahasan berkenaan dengan masalah social, budaya, teknologi, pertanian, intelektual sudah mulai diperkenalkan. Jumlah pokok bahasan yang demikian masih sedikit tetapi sudah mulai ada kesadaran bahwa sejarah tidak hanya berkenaan dengan kehidupan politik. Kajian sejarah menjadi beragam aspek kehidupan yang ada di dalam masyarakat. Oleh karena itu pengembangan materi sejarah merupakan suatu keharusan bagi guru sejarah sehingga pembelajaran sejarah tidak terpaku pada texbooks saja. 
Guru sejarah dapat mengembangkan materi sejarah dengan mengaitkannya pada sejarah lokal yang ada di daerah tersebut. Tujuanya adalah perserta didik mengetahui dan memahami peristiwa sejarah yang terjadi di daerahnya pada masa lampau. Peserta didik dapat langsung mengaitkannya dengan kondisi pada masa kini dan bahkan memproyeksikan pada masa yang akan datang. Uraian sejarah nasional maupun sejarah dunia yang sedang diajarkan dikaitkan dengan contoh-contoh dari peristiwa masa lampau.

Sebagai contoh, ketika materi pelajaran yang sedang dibahas tentang Penjajahan Jepang di Indonesia, maka guru selain menjelaskan peristiwa yang terjadi dalam ruang lingkup nasional harus juga memberikan gambaran bagaimana daerah di lingkungan sekitarnya pada periode tersebut. Namun yang terpenting adalah materi sejarah lokal harus disajikan dari sudut pandang pendidikan bukan ilmu sejarah. Penafsiran materi sejarah lokal jangan sampai menimbulkan konflik dengan ruang lingkup materi sejarah nasional dan upaya membangun rasa persatuan, kebangsaan, dan kerjasama antar daerah dalam membangun kebersamaan dalam naungan suatu negara. Oleh karena itu guru sejarah dituntut untuk lebih kreatif mengembangkan materi ajar sejarah dengan mengaitkannya pada sejarah lokal agar lebih bermakna dan membangun berbagai nilai positif pada diri peserta didik.

Pengembangan materi ajar sejarah lokal dapat dikembangkan dalam dua bentuk yaitu secara deduktif atau induktif. Deduktif yaitu dengan cara menjelaskan persoalan-persoalan umum yang terjadi pada tingkat dunia (internasional), kawasan (regional), nasional (negara), hingga pada level lokal (propinsi, kabupaten, kecamatan, desa). Sedangkan induktif kebalikan dari hal tersebut. Contoh deduktif seperti ketika guru menerangkan Revolusi Perancis dan Revolusi Amerika yang melahirkan nasionalisme, guru dapat mengaitkan konsep revolusi dan nasionalisme itu dengan yang terjadi di Indonesia, Riau, Indragiri Hulu, Rengat dan sebagainya. Sedangkan contoh dari induktif yaitu ketika guru sedang menjelaskan peninggalan sejarah perjuangan Tuanku Tambusai, yang berarti menerangkan tentang masa kolonilisme dan imperialisme. Maka guru dapat mengkaitkannya dengan Proses masuknya VOC di Surakarta, hingga Penjajahan Belanda di Nusantara.

Materi ajar Sejarah Indonesia kelas XI SMA dapat dikembangkan dengan sejarah lokal yang ada di daerah Riau. Berdasarkan dokumen silabus Sejarah Indonesia kelas XI SMA, terdapat beberapa kompetensi dasar yang materi pokoknya dapat dikembangkan dengan sejarah lokal yang ada di Riau. Kompetensi dasar yang dimaksud sebagai berikut. Pertama, menganalisis strategi perlawanan bangsa Indonesia terhadap penjajahan bangsa Barat di Indonesia sebelum dan sesudah abad ke-20 dapat dikaitkan dengan sejarah lokal di Riau seperti Perang Gutung, Perang Mondang Kumango, Perlawanan 
Rakyat Reteh, Perang Manggris dan Perlawanan Lanun di Peraiaran Riau. Kedua, menganalisis persamaan dan perbedaan pendekatan dan strategi pergerakan nasional di Indonesia pada masa awal kebangkitan nasional, Sumpah Pemuda dan sesudahnya sampai dengan Proklamasi Kemerdekaan dapat dikaitkan dengan sejarah lokal di Riau seperti lahirnya kebangkitan nasional di Riau.

Ketiga, menganalisis peran tokoh-tokoh Nasional dan Daerah dalam perjuangan menegakkan negara Republik Indonesia dapat dikaitkan dengan sejarah lokal di Riau seperti Perjuangan Tuanku Tambusai, Perlawanan Raja Haji, Perlawanan Sultan Zainal Abidin, dan Perlawanan Datuk Tabano. dan Keempat, menganalisis peristiwa proklamasi kemerdekaan dan maknanya bagi kehidupan sosial, budaya, ekonomi, politik, dan pendidikan bangsa Indonesia dapat dikaitkan dengan sejarah lokal di Riau seperti peristiwa sekitar proklamasi yang ada di daerah-daerah Riau (Pekanbaru, Tembilahan, Siak Sri Indrapura, Pasir Pengaraian, Bangkinang, Pelalawan dan Kuantan). Adapun ringkasan materi sejarah lokal yang ada di Riau yang dapat dikaitkan oleh guru sejarah dengan empat kompetensi dasar tersebut akan diuraikan sebagai berikut.

Reteh merupakan wilayah kekuasaan Kerajaan Melayu Riau yang terletak di sepanjang Sungai Gangsal. Belanda memecat Sultan Mahmud Muzaffar Syah dan mengangkat Sultan Suleiman sebagai Raja Kerajaan Melayu Riau pada tahun 1857. Para pengikut Sultan Mahmud terus melakukan perlawanan terhadap Belanda. Pengikut setia Sultan Mahmud yaitu Panglima Besar Sulung terus berjuang melawan belanda. Benteng Panglima Besar Sulung terletak di Hulu Sungai Sampi, tidak begitu jauh dari Kuala Reteh. Pada 13 Oktober 1858, pasukan Panglima Besar Sulung telah terkepung dari segala penjuru. Pada 15 Oktober 1858, pasukan Belanda mulai memasuki Sungai Sampi untuk mendekati kubu pusat pertahanan rakyat Reteh.

Pada 28 Oktober 1858, Belanda mendatangkan bantuan dari Tanjung Pinang. Pada 4 November 1858 dengan kekuatan penuh, Belanda melakukan penyerbuan ke benteng pertahanan Reteh. Belanda melakukan serangan mendadak dari darat dan berhasil masuk ke dalam benteng. Panglima Besar Sulung sebelumnya telah terkena peluru Belanda saat memeriksa tembok benteng di lehernya tepat di atas tulang dada sehingga di bawa keluar benteng. Tengku Besar Sulung dibawa ke Malaka namun meninggal dalam perjalanan.

Penaklukan yang dilakukan oleh Belanda terhadap Kerajaan Melayu Riau pada tahun 1784 melahirkan perlawanan yang secara diam-diam telah diorganisir suatu gerakan yang dikenal dengan nama Gerakan Lanun. Gerakan 
ini bertujuan merebut kembali kedaulatan Kerajaan Melayu Riau. Gerakan Lanun melakukan aksinya dengan merampok setiap kapal asing yang memasuki perairan Riau. Pada 28 Juni 1837, terjadi pertempuran yang sengit di Pulau Galang. Pertempuran tersebut pecah ketika sepasukan Lanun membajak sebuah kapal perang Inggris bernama Andromache yang dipimpin oleh Kapten H.D. Chods.

Kebangkitan Nasional di Asia dan Indonesia menyebabkan timbulnya rasa kebangsaan atau kesadaran berbangsa daerah di Riau. Beberapa tokoh pelopor kebangkitan nasional Riau seperti Suman Hs dari Bengkalis, M. Yacub dari Lipat Kain, Machmud dari Pekanbaru, Hayidin Saleh dari Rengat, Astaman dari Air Tiris dan Jamal Lako Sutan dari Taluk Kuantan. Mereka secara perorangan menanamkan pengertian dan kesadaran nasionalisme sehingga berkembang di daerah Riau. Seperti Suman Hs. Dan kawan-kawan mempelopori kesadaran berbahasa nasional melalui karya kesusastraan yang dikarangnya dan menyampaikan arti serta makna Sumpah Pemuda secara diam-diam dan berantai kepada masyarakat. Jamal Lako Sutan mengadakan kegiatan-kegiatan sebagai wartawan freelance, melalui tulisan-tulisannya ia menentang politik Kolonial Belanda dan aktif di bidang pendidikan.

Kesadaran nasional yang tadinya dikembangkan secara perorangan, lambat laun bergerak secara terorganisasi setelah sampainya berita-berita pergerakan nasional. Pada tahun 1916, dengan diprakarsai oleh Haji Mohammad Amin berdiri di Pekanbaru Serikat Dagang Islam. Menyusul kemudian 1918 di Bagansiapi-api berdiri Serikat Dagang Islam. Di tahun yang sama dibentuk pula Insulinde di bawah pimpinan A. Rahman Malim Marajo dengan cabangnya di Bangkinang dipimpin oleh Marzuki Malim Marajo. Gerakan-garakan ini melahirkan beberapa peristiwa pemberontakan yang kemudian berakhir pada penangkapan tokoh-tokoh pergerakan seperti Jamal Lako yang dibuang ke Digul tahun 1938, Haji Mohd. Amin dipenjara di Betawi tahun 1934 dan Ayub Syarofi dipenjara di Padang.

Nama aslinya adalah Muhammad Saleh yang berdakwah di Tambusai sehingga bergelar Pakih Saleh. Pakih Saleh ikut berjuang melawan penjajahan Belanda yang kemudian bergelar Tuanku Tambusai. Tahun 1835 Belanda menyerang pertahanan Tambusai di Portibi yang dimenangkan oleh Belanda. Tambusai lari ke Kota Pinang kemudian ke Gunung Intan dan akhirnya kembali ke Dalu-Dalu. Belanda menyerbu Dalu-Dalu dari dua jalur yaitu Gunung Intan di utara dan Pasir Pengaraian di Selatan. Seluruh kubu Tuanku Tambusai berhasil dikuasai, Tuanku Tambusai mundur di Benteng Aur Berduri. Setelah Benteng berhasil dikuasai Belanda, Tambusai melarikan diri ke Malaka. 
Sultan Zainal Abidin bertekad mempersatukan Kerajaan Rokan sebagaimana yang terdapat dalam Trombo Siri Kerajaan Tambusai Lama yang salah satu isinya adalah menentang penjajahan Belanda. Pada tahun 1901, Belanda menduduki daerah Rokan Empat Koto, Kerajaan Kunto Darussalam, Rambah, Tambusai dan Kepenuhan. Pada tahun 1904, Belanda melakukan penyerbuan ke Rantau Kasai, pasukan Sultan Zainal Abidin dapat dikalahkan. Sultan Zainal Abidin dipenjarakan di Pasir Pangaraian kemudian dipindahkan ke Madiun.

Belanda memasuki Bangkinang dari Muara Mahat dan Pangkalan Koto Baru pada akhir tahun 1898. Belanda berhasil menguasai pertahanan Datuk Seribu Garang. Perjuangan dilanjutkan oleh Datuk Tabano. Datuk Tabano ikut terbunuh juga dalam pertempuran tersebut.

Berita proklamasi akhirnya sampai di daerah-daerah yang ada di Riau. Beragam peristiwa mewarnai daerah-daerah di Riau seperti di Pekanbaru, Tembilahan, Siak Sri Indrapura, Pasir Pengaraian, Bangkinang, Pelalawan dan Kuantan. Bahkan etnis Tionghoa di Pekanbaru mengibarkan bendera kebangsaan mereka. Karena mereka menganggap yang berhak menggantikan pemerintahan Jepang adalah Cina, karena Cina adalah suatu negara yang menjadi anggota sekutu yang menang perang. Berita Proklamasi diterima di Pekanbaru pada akhir Agustus oleh operator atau telegrafis PTT Pekanbaru yaitu Azwar Apin dari Bukit Tinggi. Tindakan selanjutnya ialah menguasai gudang senjata Jepang di daerah Simpang Tiga. Hampir tiap rumah dan pasar yang ada di Pekanbaru mengibarkan bendera Merah Putih.

Berita proklamasi kemerdekaan pertama kali diterima di Tembilahan melalui kantor PTT Pembantu Tembilahan yaitu tanggal 25 Agustus 1945. Berita ini disampaikan dengan cara berbisik-bisik dan hati hati dikarenakan Jepang masih ditakuti. Namun akhirnya tanggal 13 September 1945 bertempat di kantor Gun Co dengan disaksikan rakyat, dikibarkanlah bendera Sang Saka Merah Putih diiringi lagu Indonesia Raya. Dalam usaha menyebarluaskan berita proklamasi dan arti kemerdekaan dikirimkanlah beberapa orang utusan ke desa-desa yang terpencil. Mereka berangkat menggunakan motor boat ke Reteh, Pulau Kijang, Sungai Batang, Sungai Teran, dan lain-lain.

Berita proklamasi di daerah Siak diterima langsung oleh Sultan. Pada tanggal 28 November 1945, Sultan Siak Sri Indrapura mengetuk kawat kepada Presiden Republik Indonesia Ir. Soekarno yang isinya menyatakan kesetiaannya kepada pemerintah RI. Selain itu, Sultan Siak juga menyerahkan harta kekayaan pribadinya kepada pemerintah yang ditaksir senilai tiga belas juta gulden serta senjata-senjata kepada tentara rakyat. Pada awal tahun 1946, 
Sultan Siak berangkat ke Medan menemui Gubernur Sumatera Mr. T. Mohammad Hasan dengan maksud membicarakan dan mendudukkan status Kerajaan Siak Sri Indrapura.

Berita Proklamasi di Bangkinang telah diketahui oleh masyarakat Bangkinang yaitu melalui penempelan teks Proklamasi pada tanggal 23 September 1945 pada pintu Kantor Muhammadiyah. Pada tanggal 25 September 1945 diadakan rapat di sekolah Muhammadiyah di Muara Jalai Air Tiris yang dipimpin oleh Mahmud Marzuki dan Haji Mohammad Amin. Salah satu keputusan rapat tersebut adalah mengibarkan Sang Saka Merah Putih. Hal tersebut dilarang oleh Kepala Polisi Bangkinang, Jamamoto karena akan menimbulkan kekacauan sebab Belanda masih berada di Bangkinang. Namun demikian, rakyat Air Tiris sempat menaikkan bendera di Kantor Muhammadiyah di Pasar Air Tiris kemudian diturunkan oleh Jepang. Akhirnya pada tanggal 12 Oktober 1945 baru dapat dikibarkan Sang Saka Merah Putih secara resmi di depan kantor Gun Co Bangkinang.

Ringkasan materi ajar sejarah lokal yang dijelaskan tersebut merupakan gambaran dari pengembangan materi ajar Sejarah Indonesia kelas XI SMA dengan sejarah lokal yang ada di Riau. Guru sejarah dapat memberikan referensi langsung dalam bentuk buku-buku bertemakan sejarah lokal yang ada di Riau atau memberikan tugas kepada peserta didik untuk mengunjungi perpustakaan daerah/wilayah untuk mencari langsung sumber referensi. Selain itu, beberapa materi sejarah lokal yang ada di Riau masih terdapat peninggalan sejarahnya. Peserta didik dengan didampingi guru sejarah dapat mengunjungi langsung peninggalan sejarah tersebut.

\section{Simpulan}

Pengembangan materi ajar sejarah dengan mengaitkannya pada sejarah lokal dapat membuat belajar sejarah menjadi lebih bermakna. Peserta didik belajar akan situasi masyarakat masa lampau yang terjadi di lingkungan sekitarnya. Peristiwa sejarah tersebut secara tidak langsung melahirkan ikatan emosional dengan kondisi lingkungan yang mereka rasakan saat ini. Dalam pembelajaran sejarah hendaknya peserta didik dapat melihat langsung kehidupan yang nyata. Oleh karena itu sejarah lokal dalam konteks pembelajaran di sekolah tidak dibatasi oleh ruang lingkup yang bersifat administratif seperti sejarah provinsi, sejarah kabupaten, sejarah kecamatan, dan sejarah desa. Berdasarkan sejarah lokal tersebut, peserta didik dapat menyadari dan lebih mengembangkan tema-tema kehidupan yang terjadi dalam lingkungan masyarakat sekitarnya, sehingga peserta didik dapat lebih memahami dan memaknai peristiwa sejarah. Guru sejarah dituntut untuk lebih mengembangkan materi ajar sejarah yang dekat dengan lingkungan 
Asyrul Fikri

Sejarah Lokal Riau untuk Pengembangan Materi Ajar Sejarah Indonesia Kelas XI SMA

peserta didik. Selain itu, diharapkan pemerintah daerah mendukung penelitian-penelitian terkait dengan sejarah lokal sehingga menambah referensi bagi guru dan peserta didik

\section{Daftar Rujukan}

Abdullah, T. (2010). Sejarah Lokal di Indonesia. Yogyakarta: Gadjah Mada University Press.

Carr, E. H. (2014). Apa itu sejarah?. Diterjemahkan Gatot Triwira. Depok: Komunitas Bambu.

Hartatik, E. S. (2007). Pemanfaatan Museum, Monumen Perjuangan, Makam Pahlawan dan Saksi Sejarah sebagai Sumber Sejarah. Makalah Seminar Peningkatan Pembinaan Kesadaran Sejarah bagi Generasi Muda Subdin Kebudayaan Dinas $P$ dan K Propinsi Jawa Tengah di Kopeng Kabupaten Semarang. Semarang.

Hasan, S. H. (2007). Problematika Pendidikan Sejarah. Bandung: FPIPS UPI.

Lapian, A. B. (2008). Pelayaran dan perniagaan Nusantara abad ke-16 dan 17. Jakarta: Komunitas Bambu.

Lestariningsih, A. D. (2007). Lawatan Sejarah Sebagai Program Strategis Dalam Meningkatkan Kesadaran Sejarah. Makalah Seminar Nasional (Tidak Diterbitkan). Unnes: Semarang.

Muslichin, M. (2011). ORANG KALANG DAN BUDAYANYA: TINJAUAN HISTORIS MASYARAKAT KALANG DI KABUPATEN KENDAL. Paramita: Historical Studies Journal, 21(2).

Nurjanto. (2007). Wisata Sejarah sebagai Salah Satu Upaya Menelusuri Perjalanan Sejarah Bangsa. Makalah Peningkatan Pembinaan Kesadaran Sejarah bagi Generasi Muda. Subdin Kebudayaan Propinsi Jawa Tengah.

Wasino, W. J., \& Cina, W. (2007). Dari Riset Hingga Tulisan Sejarah. Semarang: Unnes Press.

Widja, I. G. (1989). Sejarah Lokal Suatu Perspektif Dalam Pengajaran Sejarah. Jakarta: Jakarta: Depdikbud, Dirjen Dikti, Proyek Pengembangan Lembaga Pendidikan ....

Widodo, T. (2009). Comparative advantage: theory, empirical measures and case studies. Review of Economic and Business Studies (REBS), (4), 57-82.

Zuhdi, S. (2007). Lawatan Sejarah sebuah Tawaran Metode Efektif untuk Pembelajaran Sejarah. Makalah Seminar Nasional. Semarang: Unnes Press. 